\title{
Heat Induced Epitope Retrieval (HIER) Assisted Protein Immunostaining in Maize
}

Katsutoshi Tsuda ${ }^{1,2, *}$ and George Chuck ${ }^{3}$

\begin{abstract}
${ }^{1}$ National Institute of Genetics, Mishima, Shizuoka 411-8540, Japan; ${ }^{2}$ Department of Genetics, School of Life Science, Graduate University for Advanced Studies, Mishima, Shizuoka 411-8540, Japan; ${ }^{3 P}$ lant Gene Expression Center, U.S. Department of Agriculture-Agricultural Research Service, Plant and Microbial Biology Department, University of California at Berkeley, Albany, California 94710, USA *For correspondence: katsuda@nig.ac.jp
\end{abstract}

[Abstract] Protein immunostaining provides important spatio-temporal information about gene expression. Even using high quality antibodies, signal reproducibility and specificity can be problematic depending on tissue fixation methods. For example, formaldehyde fixed tissues often require an epitope retrieval step to expose epitopes of interest for binding to antibodies. One way to achieve this is by using Proteinase K-assisted partial protein degradation (Smith, 1994). However, this process can often reduce, or even abolish immunostaining signals. Here we provide an alternative protocol employing heat induced epitope retrieval (HIER) that gives an improved performance for signal detection (Figure 1).

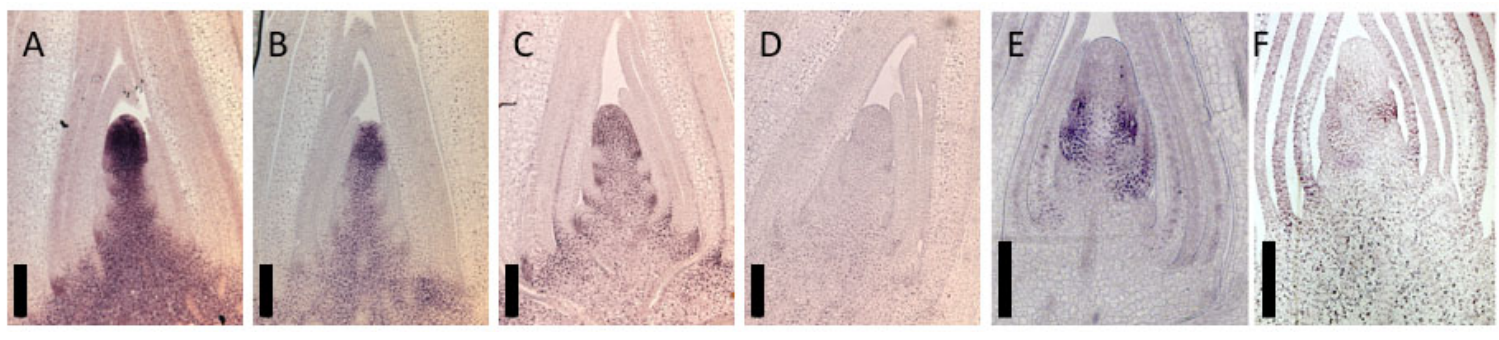

Figure 1. Comparison of HIER and ProK-assisted epitope retrieval. Immunolocalization images detected using anti-KN1 (A and B), anti-BLH14 antibodies (C and D) and anti-TSH4 (E and F). Tissue sections are subjected to $\operatorname{HIER}(A, C$ and $E)$ or Proteinase K (B, D and F)-assisted epitope retrieval. For the Proteinase $\mathrm{K}$ treatment, slides are incubated in 1 x PBS buffer containing $20 \mu \mathrm{g} / \mu \mathrm{l}$ of Proteinase K for 30 min at room temperature instead of HIER (Procedure B). Bars are $200 \mu \mathrm{m}$.

Keywords: Immunostaining, Shoot meristems, Epitope retrieval

\section{Materials and Reagents}

A. Consumables

1. Paper towels

2. Saran wrap

3. Tupperware (e.g., $15 \mathrm{~cm} \times 25 \mathrm{~cm} \times 5 \mathrm{~cm}$ for 10 slides laid flat on the bottom. See Figure 4.)

4. Glass slides (Probe-on-Plus slides) (Fisher, catalog number: 22-230-900) 


\section{Cover slips}

B. Biological material

Tissue sections ( $10 \mu \mathrm{m}$ thickness) of maize vegetative shoot apices, fixed in FAA (see Recipes) under vacuum and embedded in paraplast plus, on glass slides.

C. Reagents

1. Distilled water

2. Ethanol (99.5) (Wako, catalog number: 054-07225)

3. Ethanol solutions (Dilute ethanol (99.5) to $95,85,70$, and $50 \%$ distilled water. Stored at RT)

4. Histoclear (National Diagnostics, catalog number: HS-202)

5. Trisodium citrate dihydrate $\left(\mathrm{C}_{6} \mathrm{H}_{5} \mathrm{Na}_{3} \mathrm{O}_{7} \cdot 2 \mathrm{H}_{2} \mathrm{O}\right)$ (Wako, catalog number: 191-01785)

6. Citric acid monohydrate $\left(\mathrm{C}_{6} \mathrm{H}_{8} \mathrm{O}_{7} \cdot \mathrm{H}_{2} \mathrm{O}\right)$ (Wako, catalog number: 033-20155)

7. Sodium phosphate dibasic heptahydrate $\left(\mathrm{Na}_{2} \mathrm{HPO}_{4} \cdot 7 \mathrm{H}_{2} \mathrm{O}\right)$ (Wako, catalog number: 592-11065)

8. Potassium Dihydrogen Phosphate $\left(\mathrm{KH}_{2} \mathrm{PO}_{4}\right)$ (Wako, catalog number:169-04245)

9. Sodium chloride (NaCl) (Wako, catalog number:192-10745)

10. Potasium chloride (KCl) (Wako, catalog number:163-03545)

11. 1x phosphate-buffered saline (PBS, dilute 10x PBS with distilled water)

12. BSA (Bovine serum albumin) (Sigma-Aldrich, catalog number: A9418-100G)

13. Triton $X-100$ (Wako, catalog number: 590-18624)

14. 2-Amino-2-hydroxymethyl-1,3-propanediol (Tris) (Wako, catalog number: 204-07885)

15. Magnesium chlorate $\left(\mathrm{MgCl}_{2}\right)$ (Wako, catalog number: 136-03995)

16. Ethylenediamine- $N, N, N^{\prime}, N^{\prime}$-tetraacetic Acid Disodium Salt Dihydrate (2NA) (EDTA) (Wako, catalog number: 345-01865)

17. Primary antibody [Affinity purified KNOTTED1 (KN1), BELL1-like homeobox 14 (BLH14), and TASSELSHEATH4 (TSH4) polyclonal rabbit antibodies] (Chuck et al., 2010; Tsuda et al., 2017)

18. Secondary antibody (Alkaline phosphatase-conjugated anti-rabbit IgG antibody, Abcam, catalog number: ab97048)

19. NBT-BCIP developing reagent (Sigma-Aldrich, catalog number: 11681451001)

20. Non-aqueous mounting medium Eukitt (ORS, 6.00.01.0001.04.01.EN)

21. Glacial acetic acid (Wako, catalog number: 516-33981)

22. 37\% Formaldehyde solution (Wako, catalog number: 063-04815)

23. $10 \mathrm{mM}$ Sodium Citrate buffer $\mathrm{pH} 6.0$ (see Recipes, store at $4{ }^{\circ} \mathrm{C}$ )

24. 10x PBS buffer (Phosphate buffered saline) (see Recipes, store at RT)

25. TNM buffer (see Recipes, store at RT)

26. TE buffer (see Recipes, store at RT)

27. Blocking reagent (see Recipes)

28. Washing buffer (see Recipes)

29. Developing solution (see Recipes) 
30. FAA (see Recipes)

\section{Equipment}

1. Forceps

2. Copeland jar

3. Slide rack (Non-metal)

4. Shaker

5. Microwavable container 1 (large enough to accommodate the slide rack, e.g., $10 \mathrm{~cm} \times 10 \mathrm{~cm} \times$ $5 \mathrm{~cm})$

6. Microwavable container 2 (large enough to accommodate the container 1)

7. Microwave

8. Humid chamber-for incubation of slides with antibody

9. Microscope equipped with camera

\section{Procedure}

A. Dewax and rehydration of tissue sections

1. Transfer slides to a Copeland jar.

2. Dewax and rehydrate slides by soaking in $50 \mathrm{ml}$ of following reagents at room temperature: 100\% Histoclear for 10 min 100\% Histoclear for $10 \mathrm{~min}$ $100 \% \mathrm{EtOH}$ for 1 min $100 \% \mathrm{EtOH}$ for 1 min 95\% EtOH for $1 \mathrm{~min}$ 85\% EtOH for 1 min $70 \% \mathrm{EtOH}$ for $1 \mathrm{~min}$ $50 \% \mathrm{EtOH}$ for $1 \mathrm{~min}$ Water for $1 \mathrm{~min}$ Notes:

a The Histoclear used in the second de-waxing step can be reused several times. Disposal of Histoclear requires specialized procedures compliant with institution specific standards.

b Slides must not dry out at any time unless specified.

B. Heat induced epitope retrieval (HIER) and blocking

1. Transfer slides into a non-metal slide rack placed in a microwavable container 1.

2. Cover slides with citrate buffer $(\sim 500 \mathrm{ml})$. The buffer volume depends on the container size. Note: Add enough buffer so that the slides are not exposed to air during microwaving. The boiling buffer tends to spill out, thus requiring a second container surrounding the first one. Place 
the slides into a larger container (microwavable container 2) and cover them with saran wrap. (Figure 2).

3. Boil slides in a microwave for $10 \mathrm{~min}$.

Note: Watch that the slides do not dry out during the boiling step, if required add more hot citrate buffer. Also, this boiling step may damage tissue sections. Shortening the microwaving time (e.g., to $5 \mathrm{~min}$ ) might help tissues to keep their integrity.

4. Remove the kitchen wrap and let slides (immersed in the buffer) cool down for $\mathbf{4 0}$ min at room temperature.

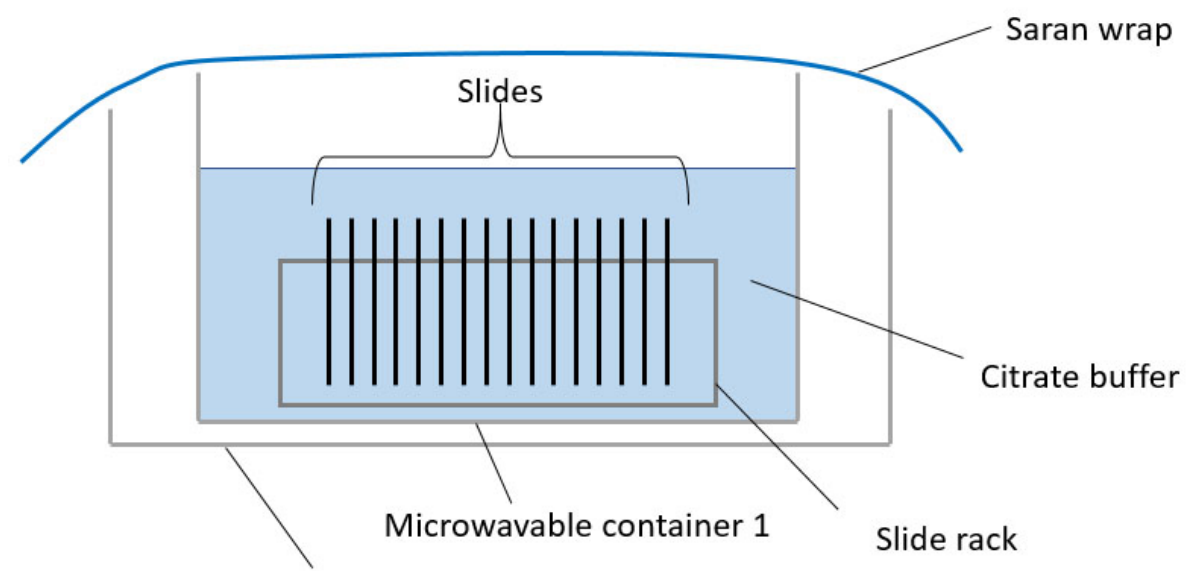

Microwavable container 2

Figure 2. Schematic representation of equipment assembly for HIER

C. Antibody labeling

1. Wash slides in $50 \mathrm{ml}$ of $1 \times$ PBS for $1 \mathrm{~min}$ in a Copeland jar.

2. Drip dry slides on paper towels by gently taping them vertically on paper towels, but do not completely dry.

3. Place slides on a flat surface and apply $200 \mu \mathrm{l}$ of Blocking Reagent to each slide. Carefully place a cover slip on the slide, avoiding air bubbles. If using Probe-on-Plus slides (Fisher), cover slips are not needed because the two slides can be pressed together to make "sandwiches." Alternatively, the slides can be laid flat in Tupperware, covered with $100 \mathrm{ml}$ of Blocking Reagent and incubated with mild shaking ( $\sim 50 \mathrm{rpm})$.

4. Incubate slides for $30 \mathrm{~min}$ at room temperature in a humid chamber (Figure 3 ). 


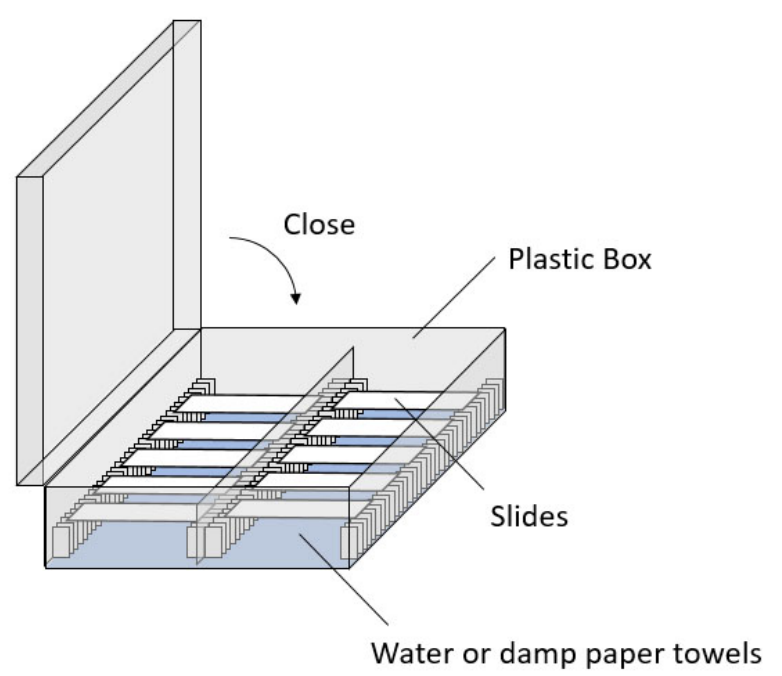

Figure 3. Schematic representation of slide incubation in a humid chamber

5. If using cover slips, remove them carefully from slides using forceps, or separate pairs of sandwiched slides by soaking them in $50 \mathrm{ml}$ of $1 \times$ PBS $1 \mathrm{mg} / \mathrm{ml}$ in a Copeland jar until cover slips fall off, or sandwiches separate. Alternatively, you can separate sandwiches carefully with forceps making sure not to touch the tissue on the slides.

6. Rinse slides once with $50 \mathrm{ml}$ of blocking solution in a Copeland jar.

7. Drip dry slides on paper towels vertically for a few seconds, but do not completely dry. Apply 100-200 $\mu \mathrm{l}$ of the primary antibody (e.g., 1:100 diluted in the blocking reagent).

8. Place a cover slip on the sections or make a sandwich with another slide if treating it with the same antibody.

9. Incubate slides in a humid chamber for 1 to $2 \mathrm{~h}$ at room temperature, or, overnight at four degrees.

10. Remove cover slips from slides or separate pairs of sandwiched slides as described earlier.

11. Lay slides down in Tupperware and cover them with $50 \mathrm{ml}$ of washing buffer for $15 \mathrm{~min}$. Oscillate the Tupperware on a shaker gently ( $\sim 50 \mathrm{rpm}$, Figure 4).

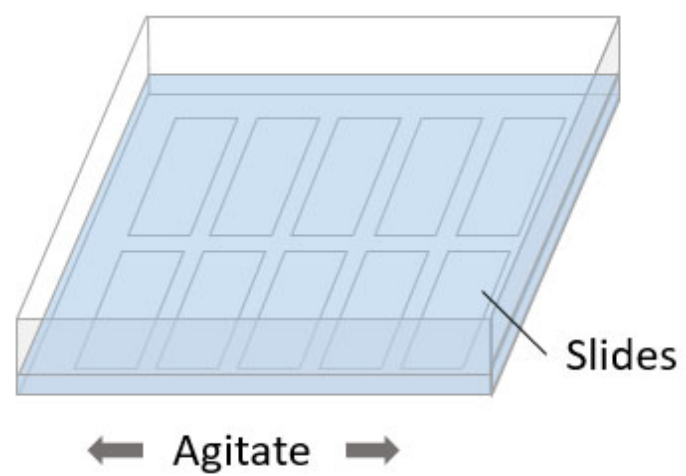

Figure 4. Schematic representation of washing step 
12. Repeat washing by replacing washing buffer twice more (three times in total).

13. Drip dry slides on paper towels as described earlier.

14. Apply $100-200 \mu \mathrm{l}$ of the secondary antibody diluted in blocking Reagent. Put a cover glass on the sections or make sandwiches as described earlier.

15. Incubate slides in a humid chamber for 1-2 $\mathrm{h}$ at RT.

16. Remove cover glasses from a slide or separate a pair of sandwiched slides as described earlier.

17. Lay slides down in a Tupperware and cover with $100 \mathrm{ml}$ of washing buffer. Oscillate the Tupperware on a shaker gently.

18. Repeat washing by replacing washing buffer twice (three times total).

19. Rinse slides for 2 min in $1 \times$ PBS.

20. Rinse slides for 10 min in TNM.

21. Drip dry slides on paper towels as described before.

22. Apply $500 \mu \mathrm{l}$ of developing solution per slide. Incubate slides in the dark at RT.

23. Observe slides as the color signal develops. In the case of KN1 and BLH14, signals usually become visible within $5 \mathrm{~min}$, but with other antibodies such as those for TSH4 it can take several hours depending on expression levels. It is very important to stop the reaction when background staining is observed, i.e., general staining in cells or tissues that should not express the protein.

24. Drip dry slides on paper towels and stop the reaction by dipping in TE.

25. Wash slides in water. Slides can be dried to completion and kept indefinitely at room temperature until ready for mounting.

D. Mounting Slides

\section{For aqueous mounting}

1. If using aqueous mounting media, add 2 to 4 drops of media to dried slides, carefully avoiding air bubbles.

2. Place cover slips and dry slides in the hood.

3. Observe and photograph with light microscope.

\section{For non-aqueous mounting}

1. Dehydrate tissue sections by incubating in $50 \mathrm{ml}$ of the following reagents in a Copland jar:

$30 \% \mathrm{EtOH}$ for $30 \mathrm{~s}$

$50 \% \mathrm{EtOH}$ for $30 \mathrm{~s}$

$70 \% \mathrm{EtOH}$ for $30 \mathrm{~s}$

$80 \% \mathrm{EtOH}$ for $30 \mathrm{~s}$

95\% EtOH for $30 \mathrm{~s}$

$100 \% 1^{\text {st }} \mathrm{EtOH}$ for $30 \mathrm{~s}$

$100 \% 2^{\text {nd }} \mathrm{EtOH}$ for $30 \mathrm{~s}$

Histoclear I for 2 min

Histoclear II for 2 min 
2. Drip dry slides as described before then add 2 to 4 drops of mounting medium. This should be done in the hood if the mounting media contains solvents such as xylene.

3. Place cover slips and dry slides in the hood.

4. Observe and photograph with a light microscope.

Note: It is important to not over-incubate slides in ethanol since long incubations will reduce signal intensity.

\section{$\underline{\text { Notes }}$}

1. Various factors such as abundance of the target protein, fixation condition, antibody quality and duration of color development affect signal intensity. As long as using the same batches of fixed samples and antibodies with the same experimental condition, the reproducibility of this method is stable in our hands.

2. Comparison between wild-type and null-mutant samples is important to distinguish immunostaining signals from non-specific background.

\section{$\underline{\text { Recipes }}$}

1. $10 \mathrm{mM}$ Sodium Citrate buffer, $\mathrm{pH} 6.0$

a. Dissolve $2.94 \mathrm{~g}$ of trisodium citrate dihydrate $\left(\mathrm{C}_{6} \mathrm{H}_{5} \mathrm{Na}_{3} \mathrm{O}_{7} \cdot 2 \mathrm{H}_{2} \mathrm{O}\right)$ in $1,000 \mathrm{ml}$ of water and adjust the $\mathrm{pH}$ to 6.0 with citric acid monohydrate $\left(\mathrm{C}_{6} \mathrm{H}_{8} \mathrm{O}_{7} \cdot \mathrm{H}_{2} \mathrm{O}\right)$

b. Store at $4{ }^{\circ} \mathrm{C}$ for up to 3 months

2. $10 x$ PBS buffer

a. Dissolve $25.6 \mathrm{~g}$ of sodium phosphate dibasic heptahydrate $\left(\mathrm{Na}_{2} \mathrm{HPO}_{4} \cdot 7 \mathrm{H}_{2} \mathrm{O}\right), 80 \mathrm{~g}$ of sodium chloride, $2 \mathrm{~g}$ of potassium chloride and $2 \mathrm{~g}$ of potassium dihydrogen phosphate $\left(\mathrm{KH}_{2} \mathrm{PO}_{4}\right)$ in $1,000 \mathrm{ml}$ of water

b. Autoclave at $120^{\circ} \mathrm{C}$ for $40 \mathrm{~min}$

c. Store at room temperature

3. TNM buffer

$100 \mathrm{mM}$ Tris- $\mathrm{HCl}$ pH 9.5

$100 \mathrm{mM} \mathrm{NaCl}$

$50 \mathrm{mM} \mathrm{MgCl}_{2}$

4. TE buffer

10 mM Tris- $\mathrm{HCl} \mathrm{pH} 8.0$

1mM EDTA

5. Blocking Reagent

1x PBS

$1 \mathrm{mg} / \mathrm{ml}$ BSA

$0.1 \%$ Triton X-100 
6. Washing buffer

1x PBS

$0.1 \%$ Triton $\mathrm{X}-100$

7. Developing solution

$20 \mu \mathrm{l}$ of NBT-BCIP in $1 \mathrm{ml}$ of $1 \times$ TNM buffer

8. FAA $(50 \mathrm{ml})$

$25 \mathrm{ml}$ ethanol

$2.5 \mathrm{ml}$ glacial acetic acid

$5 \mathrm{ml} 37 \%$ formaldehyde solution

$17.5 \mathrm{ml}$ distilled water

\section{Acknowledgments}

KT was supported by JSPS KAKENHI $16 \mathrm{H} 18637$ and $18 \mathrm{H} 04845$. GC was supported by National Science Foundation grant PGRP IOS-1339332.

Competing interests: We declare that we have no conflicting interests regarding the implementation of this protocol.

\section{References}

1. Chuck, G., Whipple, C., Jackson, D. and Hake, S. (2010). The maize SBP-box transcription factor encoded by tasselsheath4 regulates bract development and the establishment of meristem boundaries. Development 137(8): 1243-1250.

2. Smith, L. G. (1994). Immunolocalization of nuclear proteins. In: The Maize Handbook. Chapter 17 pp158-164. Springer-Verlag, New York, Inc.

3. Tsuda, K., Abraham-Juarez, M. J., Maeno, A., Dong, Z., Aromdee, D., Meeley, R., Shiroishi, T., Nonomura, K. I. and Hake, S. (2017). KNOTTED1 cofactors, BLH12 and BLH14, regulate internode patterning and vein anastomosis in maize. Plant Cell 29(5): 1105-1118. 